\title{
SISTEM PAKAR UNTUK MENDIAGNOSA PENYAKIT TANAMAN KOPI BERBASIS WEB
}

\author{
M. Junius Effendi $* 1$, Medi Triawan ${ }^{2}$ \\ ${ }^{1,2}$ Program Studi Manajemen Informatika, AMIK Lembah Dempo, Pagar Alam \\ ${ }^{2,3}$ AMIK Lembah Dempo; Jl. H. Sidik Adim No.98 Jembatan Beringin \\ Kota Pagar Alam Sumatera Selatan, Telp (0730) 624445 /Fax. (0730) 623259 \\ e-mail: **1Junius04@ lembahdempo.ac.id,$\underline{2 \text { medytriawan@ lembahdempo.ac.id }}$
}

\begin{abstract}
Abstrak
Kota Pagar Alam terkenal dengan produksi tanaman perkebunan utamanya yaitu tanaman kopi karena sebagian besar penduduk atau masyarakat bermata pencarian sebagai petani kopi sehingga fluktuasi harga kopi cukup berpengaruh terhadap ekonomi secara makro. Implementasi sistem pakar dalam industri pertanian kopi dapat gunakan oleh para petani khususnya di Kota Pagaralam untuk mendapatkan informasi diagnosa penyakit yang sering menyerang tanaman kopi serta dapat membantu peran pemerintah dalam meningkatkan produktivitas hasil panen dari tanaman kopi. Peneliti merumuskan masalah melalui studi literatur, wawancara dan observasi, menggunakan pendekatan forward channing dalam mendiagnosa penyakit tanaman kopi serta mendokumentasikan seluruh proses penelitian, mencatat setiap temuan, menyimpulkan hasil penelitian, memberikan saran dan rekomendasi untuk kepentingan penelitian selanjutnya.
\end{abstract}

Kata Kunci-Forward Chaining dan Research And Development, Kopi, SistemPakar

\begin{abstract}
The city of Pagar Alam is famous for the production of its main plantation crops, namely coffee plants because most of the residents or communities are looking for coffee farmers so that the fluctuations in coffee prices are quite influential on the macro economy. The implementation of an expert system in the coffee farming industry can be used by farmers, especially in the City of Pagaralam to obtain information on the diagnosis of diseases that often attack coffee plants and can help the government's role in increasing the productivity of crops from coffee plants. The researcher formulated the problem through literature studies, interviews and observations, using a forward channing approach in diagnosing coffee plant diseases and documenting the entire research process, recording each finding, concluding the results of the research, providing suggestions and recommendations for the purposes of further research.
\end{abstract}

Keywords-Forward Chaining and Research And Development, Coffee, Expert Systems 


\section{PENDAHULUAN}

Kota Pagaralam terkenal dengan produksi tanaman perkebunan utamanya yaitu tanaman kopi karena sebagian besar penduduk atau masyarakat Pagaralam bermata pencarian sebagai petani kopi sehingga fluktuasi harga kopi cukup berpengaruh terhadap ekonomi secara makro. Tidak sedikit masyarakat yang meningkatan kesejateraan hidupnya melalui bercocok tanam kopi. Berdasarkan katalog Badan Pusat Statistik (BPS) 1102001.1673 Kota Pagaralam pada tahun 2015 adapun Luas lahan perkebunan kopi di Kota Pagaralam hanya 8.321 hektar (ha) dengan volume produksi rata-rata $7.465,50$ ton per tahun.

Tabel 1. Luas Wilayah dan Luas Perkebunan Pagar Alam

\begin{tabular}{|l|c|c|}
\hline Kecamatan & $\begin{array}{c}\text { Luas } \\
\text { Wilayah } \\
\left(\mathbf{k m}^{2}\right)\end{array}$ & $\begin{array}{c}\text { Luas } \\
\text { Perkebunan } \\
\text { Kopi (Ha) }\end{array}$ \\
\hline $\begin{array}{l}\text { Pagar } \\
\text { Alam }\end{array}$ & & 709,00 \\
Utara & 54,55 & \\
\hline $\begin{array}{l}\text { Pagar } \\
\text { Alam } \\
\text { Selatan }\end{array}$ & 62,17 & 876,00 \\
\hline $\begin{array}{l}\text { Dempo } \\
\text { Tengah }\end{array}$ & 173,10 & 2970,00 \\
\hline $\begin{array}{l}\text { Dempo } \\
\text { Utara }\end{array}$ & 123,98 & 289,00 \\
\hline $\begin{array}{l}\text { Dempo } \\
\text { Selatan }\end{array}$ & 239,08 & 872,00 \\
\hline
\end{tabular}

Salah satu masalah utama dalam industri pertanian kopi adalah minimnya pengetahuan dari petani serta kurangnya sosialisasi dari dinas terkait dengan hama atau penyakit dari tanaman kopi. Selain itu, kurangnya pembelajaran terhadap cara menanam kopi yang baik dapat menimbulkan serangan penyakit tanaman kopi pada akar, batang, buah maupun daun sehingga bisa mempengaruhi hasil panen.Untuk meningkatkan pengetahuan petani kopi tentang penyakit kopi adalah melalui sosialisasi langsung terhadap kelompok tani yang melibatkan pakar kopi atau petani yang sudah sukses dalam mengolah kopi. Namun, keterbatasan para ahli atau pakar kopi menjadikan salah satu faktor yang menjadi kendala dalam melakukan sosialisasi langsung kepada kelompok tani.Durkin dalam Daniel dan Virginia (2010) juga menyebutkan hal yang senada bahwa sistem pakar adalah sistem yang berusaha mengadopsi pengetahuan manusia ke komputer yang dirancang untuk memodelkan kemampuan menyelesaikan masalah seperti layaknya seorang pakar .[1]

Diharapkan dengan adanya sistem pakar yang mampu diakses oleh para petani khususnya di Kota Pagaralam, dapat memberikan pengetahuan dan solusi terhadap hama atau penyakit kopi sehingga kelompok tani dapat meningkatkan produktivitas dari hasil petani. Dari hasil permasalahan tersebut penulis mengangkat judul penelitian Sistem Pakar Untuk Mendiagnosa Penyakit Tanaman Kopi Berbasis Web di Kota Pagaralam.

\section{TINJAUAN PUSTAKA}

\subsection{Sistem Pakar}

Sistem pakar merupakan cabang kecerdasan buatan yang dimiliki. Sebagian besar dampaknya, terutama di dunia kedokteran, keuangan, telekomunikasi, layanan pelanggan, transportasi, penerbangan, dan akhir-akhir ini, komunikasi tertulis. Pembuatan sistem intelijen berdasarkan sistem pakar dengan menggunakan teknologi seperti pembelajaran mesin, bahasa alami pengolahan, pengenalan suara dan penglihatan mesin, semua yang merupakan pusat sistem yang sangat maju [2].

\subsection{Komponen-komponen Sistem Pakar \\ Komponen sistem pakar terdiri dari} mesin kesimpulan, basis pengetahuan, memori kerja, dan antarmuka pengguna. Basis pengetahuan terdiri dari satu set eksplisit aturan dinyatakan dalam bentuk: if 
<condition> then <konsekuensi>. Mesin inferensi mengevaluasi aturan, sedangkan memori kerja digunakan untuk menyimpan nilai arus Parameter, biasanya didapat melalui user interface dan dievaluasi terhadap kondisi saat ini [3].

\subsection{Kopi}

Kopi merupakan komoditas dengan pasar internasional yang besar. Minuman ini dinilai berdasarkan parameter kualitatif. Dengan demikian, menghasilkan kopi berkualitas unggul merupakan isu strategis untuk kopi tumbuh. Adopsi teknik bertujuan memberi nilai tambah pada kopi bisa membawa banyak manfaat untuk kopi tumbuh, karena, ini adalah tanaman dengan pendapatan tinggi per area, berdasarkan harganya pada kualitas biji-bijian, misalnya mengklaim bahwa pengetahuan tentang standar kualitas produk pertanian yang berbeda memungkinkan menangani keragaman alam yang ada di daerah penghasil, terutama melalui beberapa pilihan kritis, terutama mengenai pemilihan varietas untuktumbuh dan penerapan praktik pengelolaan yang sesuai untuk masing-masing unit, memungkinkan untuk mendapatkan hasil kualitatif yang lebih baik [4].

\subsection{ForwardChaining}

Forwardchaining dimulai dengan data yang tersedia. Ini merupakan sebuah data awal dan menggunakan aturan inferensi untuk membantu dalam mengekstrak lebih banyak data sampai tercapai tujuan. Mesin inferensi menggunakan forward chaining untuk mencari aturan inferensi sampai menemukan satu keputusan dan menemukan solusinya. Berikut klausa "JIKA" diketahui benar, maka bisa disimpulkan hasil akhir berupa keputusan. Jika klausa "THEN" akan memberikan penambahan informasi baru ke data set. Artinya dimulai dengan beberapa fakta dan menerapkan peraturan untuk menemukan semua kemungkinan kesimpulannya. Oleh karena itu, juga dikenal sebagai " Tujuan Berdasarkan Pendekatan" [5].

\subsection{Basisdata}

SQL adalah sistem manajemen basis data OpenSource Relational yang paling populer. MySQL adalah database kecil yang ringkas, server ideal untuk aplikasi kecil dan tidak begitu kecil. Selain mendukung standar SQL (ANSI), ia mengkompilasi pada jumlah platform dan memiliki kemampuan multireading pada server UNIX, yang menghasilkan kinerja yang hebat. MySQL dapat dijalankan sebagai layanan pada Windows NT dan sebagai proses normal pada mesin Windows 95/98 [6].

\subsection{Unified Modelling Language (UML)}

Bahasa UML memasok kerangka kerja yang sesuai untuk akuisisi situasi dengan menggunakan diagram usecase seperti urutan, diagram kolaborasi didefinisikan sebagai skenario ilustrasi dari usecase yang diberikan. Skenario dilihat di dua pendekatan eksklusif melalui diagram urutan dan diagram kolaborasi. Setiap variasi diagram tergantung pada semantik yang mendasarinya .[7] [8]

\section{METODOLOGI PENELITIAN}

Tahapan yang dilakukan peneliti dalam penelitianini adalah sebagai berikut:

1. Tahapan Studi Pendahuluan

Pada tahap studi pendahuluan merupakan tahap perencanaan, dimana dalam tahapan ini peneliti mencoba merumuskan masalah dengan menganalisa kebutuhan sistem. Pada tahapan ini juga dilakukan proses pengumpulan data yang meliputi data primer dan data sekunder. Berikut ini merupakan metode pengumpulan yang dilakukan oleh penulis seperti studi literatur, wawancara dan observasi. Tahapan ini akan menghasilkan functional requirement untuk perancangan sistem pakar untuk mendiagnosa penyakit tanaman kopi.

2. Tahapan Pengembangan Sistem

Pada tahap pengembangan, peneliti melakukan desain sistem berdasarkan functional requirement. Hasil desain sistem yang dihasilkan terdiri dari usecase diagram, class diagram, 
activity diagram dan sequence diagram. Sistem pakar untuk mendiagnosa penyakit tanaman kopi dibangun dengan menggunakan pendekatan forward channing. Output dari tahapan ini merupakan aplikasi sistem pakar untuk mendiagnosa penyakit tanaman kopi.

3. Tahapan Evaluasi

Dalam tahap evaluasi, peneliti akan melakukan proses pengujian terhadap sistem pakar untuk mendiagnosa penyakit tanaman kopi, dalam tahap evaluasi juga dilakukan validasi terhadap desain sistem oleh pakar tanaman kopi. Output dari tahapan ini merupakan pembahasan hasil pengujian sistem.

4. Tahapan Dokumentasi

Tahap dokumentasi merupakan tahap final dari seluruh rangkaian penelitian. Tahapan ini mendokumentasikan seluruh proses penelitian, mencatat setiap temuan, menyimpulkan hasil penelitian, memberikan saran dan rekomendasi untuk kepentingan penelitian selanjutnya. Untuk lebih jelasnya mengenai fase-fase penelitian tersebut dapat dilihat pada gambar 1 berikut ini:

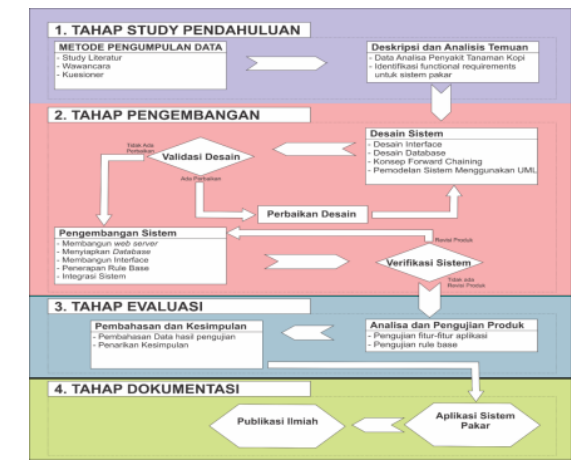

Gambar 1 Skema Penelitian

\section{HASIL DAN PEMBAHASAN}

Analisis Data rerata Penyakit Pada

Tanaman Kopi berdasarkan jumlah produksi pada tahun 2015 dan 2016 untuk 5 kecamatan di kota Pagar Alam.
Tabel 2. Persentase Penyakit Tanaman

\begin{tabular}{|l|c|c|c|c|c|c|}
\multicolumn{2}{c|}{ Kopi } \\
\hline \multirow{3}{*}{ Kecam atan } & \multicolumn{7}{|c|}{ Persentase Penyakit Tanaman Kopi } \\
\cline { 2 - 7 } & 1 & 2 & 3 & 4 & 5 & 6 \\
\hline Pagar Alam Utara & $11 \%$ & $17 \%$ & $23 \%$ & $16 \%$ & $18 \%$ & $15 \%$ \\
\hline Pagar Alam Selatan & $20 \%$ & $14 \%$ & $15 \%$ & $21 \%$ & $14 \%$ & $16 \%$ \\
\hline Dempo Tengah & $17 \%$ & $16 \%$ & $18 \%$ & $17 \%$ & $16 \%$ & $16 \%$ \\
\hline Dempo Utara & $15 \%$ & $18 \%$ & $17 \%$ & $17 \%$ & $17 \%$ & $16 \%$ \\
\hline Dempo Selatan & $21 \%$ & $19 \%$ & $15 \%$ & $13 \%$ & $14 \%$ & $18 \%$ \\
\hline
\end{tabular}

Keterangan Penyakit:

1. Karat Daun Kopi (Hemileia Vastatrix)

2. Bercak Daun Kopi (Mycosphaerella Coffeicola)

3. Jamur Upas (Corticium Salmonicolor)

4. Penyakit Akar : Hitam, Coklat dan Putih (Phellinus noxius, Rosellinia bunodes, dan Rigidoporus microporus)

5. Nematoda (Pratylenchus Coffeae dan Radopholus Similis)

6. Lain - lain

\subsection{Analisa Sistem Yang Berjalan}

Kota Pagar Alam terkenal dengan produksi tanaman perkebunan utamanya yaitu tanaman kopi karena sebagian besar masyarakat bermata pencarian sebagai petani kopi sehingga fluktuasi harga kopi cukup berpengaruh terhadap ekonomi secara makro.Salah satu cara untuk meningkatkan pengetahuan petani kopi tentang hama atau penyakit kopi adalah melalui sosialisasi langsung terhadap kelompok tani yang melibatkan pakar kopi atau petani yang sudah sukses dalam mengolah kopi. Namun, keterbatasan para ahli atau pakar kopi menjadikan salah satu sistem yang menjadi kendala dalam melakukan sosialisasi langsung kepada kelompok tani serta kurangnya pengetahuan petani terkait dengan penyakit hama tanaman kopi ini.

Dari analisa yang telah dilakukan pada ystem yang berjalan maka peneliti menyimpulkan beberapa kendala yang dihadapi diantaranya sebagai berikut:

1. Kurangnya sosialisasi dinas terkait terhadap hama penyakit tanaman kopi dan perkembangannya secara berkala kepada kelompok tani;

2. Kurangnnya ahli atau pakar tanaman kopi di Kota Pagar Alam

3. Kurangnya pemahaman petani tentang hama penyakit tanaman kopi, serta solusi cara mengatasi hama tersebut. 


\subsection{Analisa Sistem Yang Diusulkan}

Dengan adanya kelemahan pada sistem yang sedang berjalan, maka dibentuklah sistem yang baru, dengan ini diharapkan dapat berjalan dengan optimal sehingga dapat memberikan manfaat yang berguna bagi para pengguna sistem, berikut gambaran dari sistem pakar yang akan dibangun oleh peneliti.

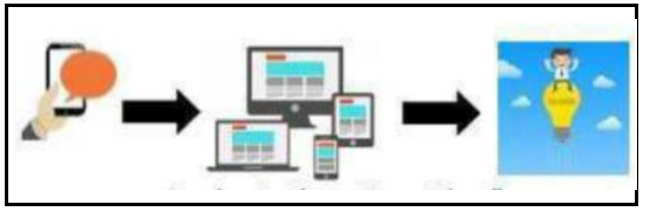

Gambar 2 Sistem Yang Diusulkan

Berikut penjelasan singkat mengenai sistem yang akan dibuat :

1. User membuka sistem diagnosa hama penyakit tanaman kopi baik dari komputer ataupun handphone;

2. Pada halaman website tersebut user bisa melakukan beberapa fitur antara lain konsultasi, pertanyaan, dan lain sebagainya.

3. Userakan menerima laporan berupa solusi berdasarkan hasil konsultasi dengan sistem pakar.

Pada tahapan ini dilakukan analisis kebutuhan sistem yang akan diusulkan, analisis dilakukan berdasarkan dari data literature yang didapat. Sistem pakar diagnosa hama penyakit tanaman kopi yang akan diusulkan harus memenuhi kreteria sebagai berikut:

1. Sistem harus userfriendly yakni mudah dipahami dan digunakan.

2. Dengan adanya sistem pakar ini dapat meminimalkan atau mengefektifkan dan menghemat biaya dalam proses pencarian informasi karena sistem merupakan aplikasi yang berbasis web.

3. Dalam sistem, user dapat melakukan konsultasi mengenai penyakit yang dialami tanaman kopi serta mendapatkan solusi dari hasil konsultasi dengan aplikasi.

\subsection{Desain Sistem}

\section{Usecase Diagram}

Pada Aplikasi sistem pakar terdapat 2 aktor yaitu Admin dan user (pengunjung), untuk lebih jelasnya dapat dilihat pada gambar 3 berikut ini:

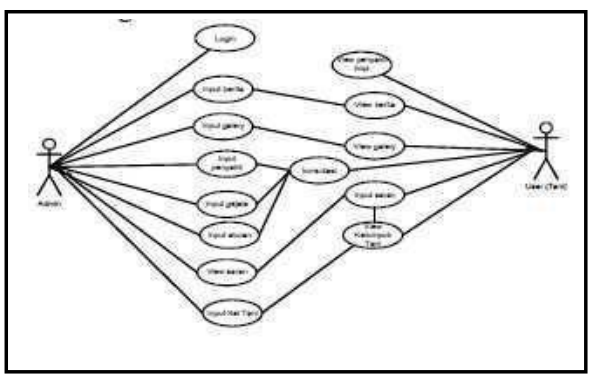

Gambar 3 Usecase Diagram

\section{Class Diagram}

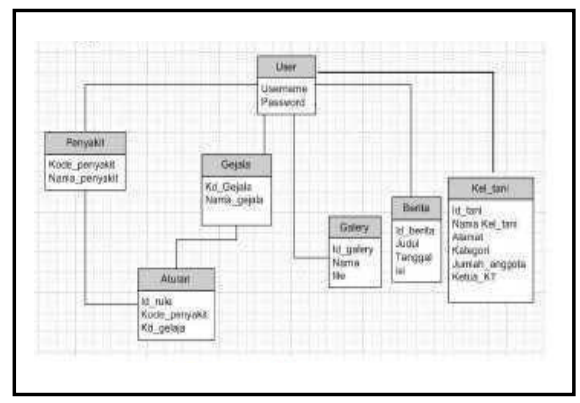

Gambar 4 Class Diagram

3. Activity Diagram User

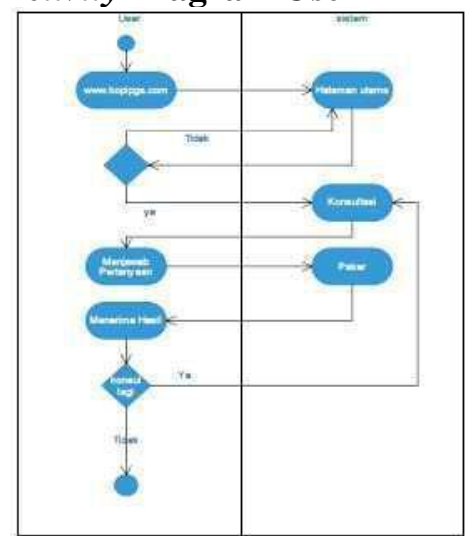

Gambar 5 Activity Diagram User 


\section{Sequence Diagram User}

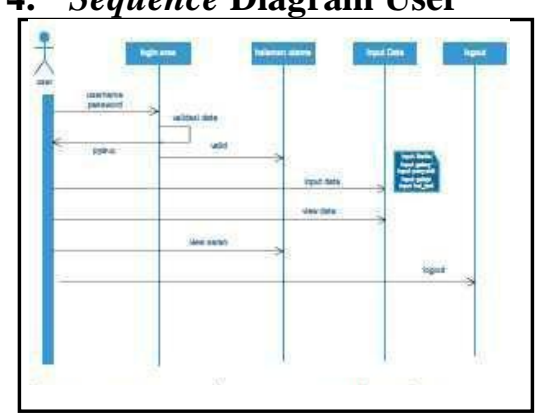

Gambar 6 Sequence Diagram User

Dalam desain Uji coba ini menggunakan Metode Forwardchaining, Berikut rule yang didapatkan berdasarkan analisa dari penelitian penulis:

Tabel 3. Gejala Penyakit Tanaman Kopi

\begin{tabular}{|c|c|}
\hline $\begin{array}{l}\text { No } \\
\text { ID }\end{array}$ & Gejala \\
\hline ID001 & $\begin{array}{l}\text { Apakah Daun menguning dan } \\
\text { gugur? }\end{array}$ \\
\hline ID002 & $\begin{array}{l}\text { Apakah Bercak yang timbul } \\
\text { pada daun berwarna kuning } \\
\text { muda yang berubah menjadi } \\
\text { kuning tua? }\end{array}$ \\
\hline ID003 & $\begin{array}{l}\text { Apakah Bercak makin lama } \\
\text { membersar dan menyatu? }\end{array}$ \\
\hline ID004 & $\begin{array}{lll}\begin{array}{l}\text { Apakah } \\
\text { gundul? }\end{array} & \text { Pohon } & \text { menjadi } \\
\end{array}$ \\
\hline ID005 & $\begin{array}{l}\text { Apakah Permukaan bercak pada } \\
\text { sisi bawah daun terdapat } \\
\text { uredospora seperti tepung } \\
\text { berwarna oranye atau jingga? }\end{array}$ \\
\hline ID006 & $\begin{array}{l}\text { Apakah Timbul bercak-bercak } \\
\text { pada daun? }\end{array}$ \\
\hline ID007 & $\begin{array}{l}\text { Apakah Bercak yang timbul } \\
\text { pada daun berwarna coklat } \\
\text { berbentuk lingkaran, putih pada } \\
\text { tengahnya dan merah } \\
\text { dipinggirnya? }\end{array}$ \\
\hline ID008 & $\begin{array}{l}\text { Apakah Pada buah timbul } \\
\text { bercak berwarna coklat? }\end{array}$ \\
\hline ID009 & $\begin{array}{l}\text { Apakah Pada buah dewasa } \\
\text { berkerut dan masak sebelum } \\
\text { waktunya? }\end{array}$ \\
\hline ID010 & $\begin{array}{l}\text { Apakah ada benang-benang } \\
\text { jamur tipis seperti sutera, } \\
\text { berbentuk sarang laba- laba } \\
\text { pada Batang, Cabang, Ranting } \\
\text { atau Buah? }\end{array}$ \\
\hline
\end{tabular}

\begin{tabular}{|l|l|}
\hline ID011 & $\begin{array}{l}\text { Apakah pada sisi bawah cabang } \\
\text { yang agak ternaung terdapat } \\
\text { lapisan kerak berwarna merah } \\
\text { jambu terdiri atas himenium? }\end{array}$ \\
\hline ID012 & $\begin{array}{l}\text { Apakah Tanaman } \\
\text { mengering/hitam? }\end{array}$ \\
\hline ID013 & $\begin{array}{l}\text { Apakah Daun menguning dan } \\
\text { gugur? }\end{array}$ \\
\hline ID014 & $\begin{array}{l}\text { Apakah Daun hijau } \\
\text { kekuningan, kusam, tampak } \\
\text { layu serempak dan tampak } \\
\text { menggantung? }\end{array}$ \\
\hline ID015 & $\begin{array}{l}\text { Apakah Akar tunggang } \\
\text { tertutup kerak butir-butir tanah } \\
\text { yang melekat kuat? }\end{array}$ \\
\hline ID016 & $\begin{array}{l}\text { Apakah Akar diantara butiran } \\
\text { tanah tampak adanya anyaman } \\
\text { benang jamur } \\
\text { kehitaman? }\end{array}$ \\
\hline ID017 & $\begin{array}{l}\text { Apakah Akar yang sakit akan } \\
\text { membusuk, kering dan lunak? }\end{array}$ \\
\hline ID018 & $\begin{array}{l}\text { Apakah Pangkal batang dan } \\
\text { permukaan kayu akar terdapat } \\
\text { titik-titik hitam? }\end{array}$ \\
\hline ID019 & $\begin{array}{l}\text { Apakah Daun menguning dan } \\
\text { gugur? }\end{array}$ \\
\hline ID020 & $\begin{array}{l}\text { Apakah Tanaman kopi yang } \\
\text { terserang kelihatan kerdil? }\end{array}$ \\
\hline ID021 & $\begin{array}{l}\text { Apakah Pertumbuhan cabang- } \\
\text { cabang primer terhambat? }\end{array}$ \\
\hline ID022 & $\begin{array}{l}\text { Apakah Buah prematur dan } \\
\text { banyak yang kosong? }\end{array}$ \\
\hline ID023 & $\begin{array}{l}\text { Apakah Bagian akar serabut } \\
\text { membusuk dan putus? }\end{array}$ \\
\hline
\end{tabular}

Tabel 4. Penyakit Tanaman Kopi

\begin{tabular}{|c|l|}
\hline $\begin{array}{c}\text { Kd } \\
\text { Penyakit }\end{array}$ & \multicolumn{1}{|c|}{ Nama Penyakit } \\
\hline P1 & $\begin{array}{l}\text { Karat Daun Kopi (Hemileia } \\
\text { Vastatrix) }\end{array}$ \\
\hline P2 & $\begin{array}{l}\text { Bercak Daun Kopi } \\
\text { (MycosphaerellanCoffeicola) }\end{array}$ \\
\hline P3 & $\begin{array}{l}\text { Jamur Upas (Corticium } \\
\text { Salmonicolor) }\end{array}$ \\
\hline P4 & $\begin{array}{l}\text { Penyakit Akar : Hitam, } \\
\text { Coklat dan Putih (Phellinus } \\
\text { noxius, Rosellinia bunodes, } \\
\text { dan Rigidoporus } \\
\text { microporus) }\end{array}$ \\
\hline P5 & $\begin{array}{l}\text { Nematoda (Pratylenchus } \\
\text { Coffeae dan Radopholus } \\
\text { Similis) }\end{array}$ \\
\hline
\end{tabular}




\subsection{TampilanAplikasi Sistem Pakar}

Tampilan Aplikasi Sistem pakar merupakan hasil pembangunan perangkat lunak sistem pakar untuk mendiagnosa penyakit tanaman kopi berbasis web.

1. Tampilan Halaman Utama

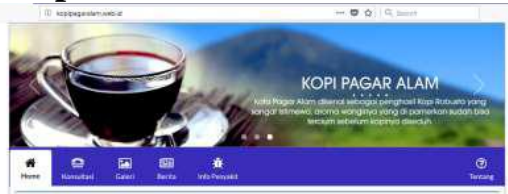

Gambar 7 Tampilan Halaman Utama

\section{Tampilan Halaman Admin}

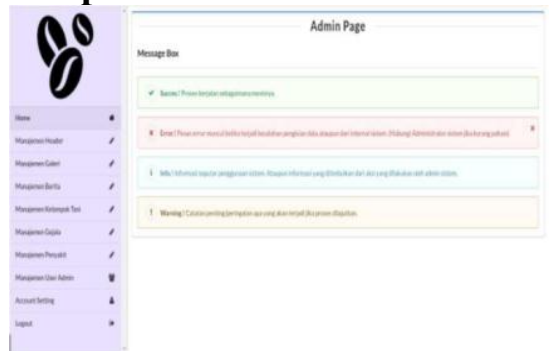

Gambar 8 Tampilan Halaman Admin

\section{Tampilan Halaman Konsultasi}

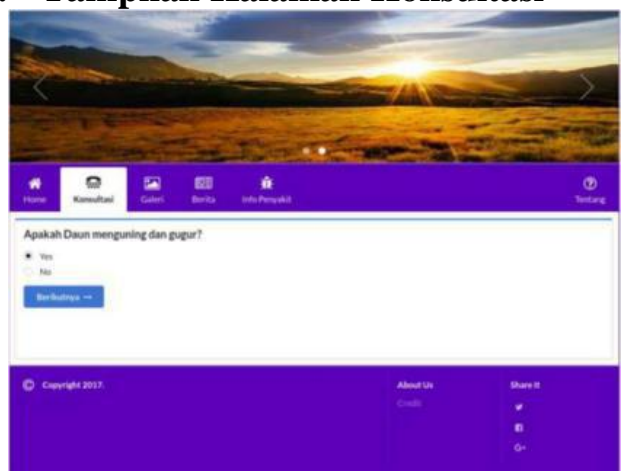

Gambar 9 Tampilan Halaman Konsultasi

\section{Tampilan Info Penyakit}

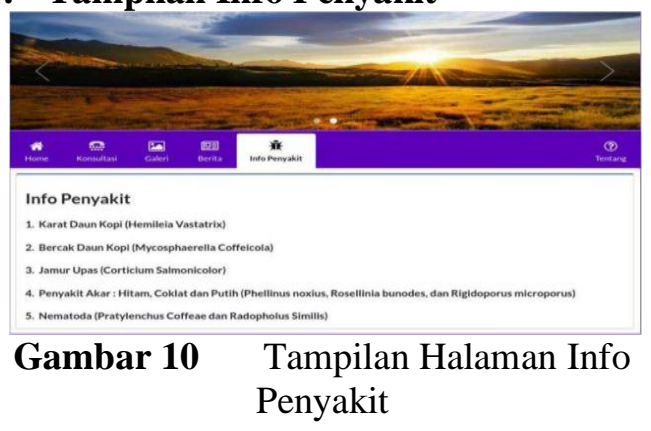

\section{KESIMPULAN}

Berdasarkan Hasil yang telah dicapai diatas, terkait dengan sistem diagnosa penyakit tanaman kopi maka dapat disimpulkan:

1. Dengan adanya sistem diagnosa pakar penyakit tanaman kopi, dapat mempermudah para petani kopi dalam mengetahui penyakit tanaman kopi sehingga menambah pengetahun bagi para petani kopi di Pagar Alam khususnya dan nusantra pada umumnya karena sistem yang dibangun adalah sistem berbasis web.

2. Dapat mempermudah Dinas Pertanian Kota Pagar Alam untuk menyampaikan informasi serta memberikan solusi sesuai hasil diagnosa kepada para petani kopi dengan adanya aplikasi ini.

3. Sistem pakar diagnosa penyakit tanaman kopi ini hanya menghasilkan penyakit yang dihasilkan dari gejala yang dialami dengan metode forward chaining.

\section{SARAN}

Sistem pakar ini yang dihasilkan belumterlalu efektif dikarenakan masih banyakkekurangan seperti solusi dalam mencegah dan lainsebagainya, maka dari pada itu perlu adanya pendalaman dan pengembangan lebih lanjut.

\section{DAFTAR PUSTAKA}

[1] Daniel and G. Virginia,“ Implementasi Sistem Pakar Untuk Mendiagnosis Penyakit Dengan Gejala Demam Menggunakan Metode Certainty Factor," $J$. Inform., vol. 6, no. 1, pp. 25-36, 2010.

[2] S. S. A. Naser and M. M. Alhanjori, "An expert system for men genital problems diagnosis and treatment," Int. J. Med. Res., vol. 1, no. 2, pp. 83-86, 2016.

[3] M. H. Saad, R. A. Shahad, K. Win, and A. Hussain, "ExSIDE: 
Component Based Object Oriented

Expert System ' s Integrated Development Environment," Int. J. INFORMATICS Vis., vol. 1, no. 3, pp. 88-95, 2017.

[4] W. P. M. Ferreira, D. M. Queiroz, S. A. Silvac, R. S. Tomaz, and P. C. Corrêa, "Effects of the Orientation of the Mountainside, Altitude and Varieties on the Quality of the Coffee Beverage from the "Matas de Minas ' Region, Brazilian Southeast," Am. J. Plant Sci., vol. 7, no. 8, pp. 1291-1303, 2016.

[5] N. Kapoor and N. Bahl, "Comparative Study of Forward and Backward Chaining in Artificial Intelligence," IJCS, vol. 5, no. 4, pp. 16239-16242, 2016.

[6] M. Koshti and S. Ganorkar, "IoT Based Health Monitoring System by Using Raspberry Pi and ECG Signal," IJIRSET, vol. 5, no. 5, pp. 8977-8985, 2016.

[7] D. Rajagopal and K. Thilakavalli, "A Study: UML for OOA and OOD," Int. J. Knowl. Content Dev. Technol., vol. 7, no. 2, pp. 5-20, 2017.

[8] A. Y. Saputra and R. Yanto, "EVoting Berbasis Web dan Wap dalam Pemilihan Kepala Desa Kabupaten Musi Rawas," J. Sisfo, vol. 5, no. 3, pp. 187-192, 2015. 